\title{
Study on City Logistics Development Based on Breaking Point Theory
}

\author{
Yanhui HAN \& Yanni ZHU \\ School of Traffic and Transportation, Beijing Jiaotong University, Beijing, China \\ Xianqiang FENG \\ Powerchina Xibei Engineering Corporation Limited, Xian, China
}

\begin{abstract}
This study used a principal component analysis, determine the comprehensive expression of principal components, obtain principal component scores on the comprehensive and rank, and then comprehensively evaluate city logistics competitiveness of 14 cities in Guangxi to quantitatively evaluate. The city breaking point theory, combined with SPSS is used to calculate the breaking point between cities to analyze city hinterland. Then combined with the advantages of location, the range of hinterland, the resources of logistics, the logistics development measures for Fangcheng-gang are proposed. The objectives are to improve the comprehensive competitiveness of Fangcheng-gang in guangxi, and provide some reference suggestion about the development of Guangxi in terms of logistics.
\end{abstract}

KEYWORD: Traffic Location; City Logistics; Breaking Point Theory; Hinterland

\section{INTRODUCTION}

Economic growth, will inevitably lead to huge material product flow, the increase of throughput and the growth of logistics industry. Transportation is the main part of modern logistics industry. Traffic location, transportation infrastructure, city attracting scope is the important guarantee of the development of modern logistics.

Scherer (1990) provided a systematic presentation of the economic field of industrial organization, which is concerned with how transportation is brought into harmony with the regional economy [1]. Patton(1958) and Morgan(1958) indicated that hinterland plays a vital role in the formation of the port, the port development is one of the important factors of regional economic growth [2-3]. Mayer(1957) put forward the competition of freight transportation of their common hinterlands [4]. Forrester(1968) proposed qualitative and quantitative analysis to predict the operation and development of ports in regional economy [5]. Wang Jie, Yang Zan, Lu Chun-feng(2005) introduced layers method and pivot and ligament method for partitioning port hinterland. Comparing with traditional methods, the two methods highlight the fine partition of existing port hinterland, are closer to the actual condition of port, and thus are more helpful for the operation development of port enterprises [6]. Xie Tongwei and Bin Changchu(2007) compared with the port in "Yangtze River Delta", "Zhujiang River Delta" and in the Bohai Bay, the relation between the port of Guangxi Beibu Bay and the port's hinterland is very poor. There are lots of problems in the port's hinterland, such as weak support of the economy in the port hinterland, coincidence of hinterland, the shrinkage of the hinterland [7]. Yan Weiyang(2004) put forward that the expanded breaking point theory and the conception of breaking arcs were contrasted to the classical theory. As a demonstration, the expanded theory was used in Henan province, and the scheme of the urban economic regions was put forward [8]. In summary, it is possible to study the city logistics competitiveness by using breaking point theory.

\section{BUILDING EVALUATION INDEX SYSTEM OF COMPREHENSIVE STRENGTH OF CITY LOGISTICS}

Evaluation index system of comprehensive strength of city logistics must be built on a scientific basis, objective, and a true reflection of the city logistics industry development. It also needs to use the existing administrative data in the statistical system. Combined with the basic connotation of industrial competitiveness and characteristics of city logistics industry, the paper builds the evaluation index system in four aspects: city economy, city infrastructure, social development and international development level [9-11]. It is shown in table 1. 
Table 1. Evaluation index system of comprehensive strength of city logistics

\begin{tabular}{|c|c|c|}
\hline Index & Item & No. \\
\hline \multirow{7}{*}{ City economy } & $\begin{array}{l}\text { Per Capita Gross Domestic Product } \\
\text { (Yuan) }\end{array}$ & $\mathrm{X}_{1}$ \\
\hline & $\begin{array}{l}\text { The Gross Value of Industrial Output } \\
\text { (100 million Yuan) }\end{array}$ & $\mathrm{X}_{2}$ \\
\hline & $\begin{array}{l}\text { Total Investment in Fixed Assets } \\
\text { (100 million Yuan) }\end{array}$ & $\mathrm{X}_{3}$ \\
\hline & $\begin{array}{l}\text { Gross Domestic Product Growth Rate } \\
\text { (annual \%). }\end{array}$ & $\mathrm{X}_{4}$ \\
\hline & $\begin{array}{l}\text { Per Capita Annual Disposable Income of } \\
\text { Urban Households (Yuan) }\end{array}$ & $\mathrm{X}_{5}$ \\
\hline & $\begin{array}{l}\text { The Third Industry Output Value } \\
\text { Accounted for the Proportion of GDP }\end{array}$ & $\mathrm{X}_{6}$ \\
\hline & $\begin{array}{l}\text { Total Retail Sales of Consumer Goods } \\
\text { (100 million Yuan) }\end{array}$ & $\mathrm{X}_{7}$ \\
\hline \multirow{4}{*}{$\begin{array}{c}\text { City } \\
\text { infrastructure }\end{array}$} & $\begin{array}{l}\text { The Total Amount of the City Passenger } \\
\text { Transport (10 000 persons) }\end{array}$ & $\mathrm{X}_{8}$ \\
\hline & $\begin{array}{l}\text { The Total Amount of the City Freight } \\
\text { Transport (10000 tons) }\end{array}$ & $\mathrm{X}_{9}$ \\
\hline & $\begin{array}{l}\text { Business Volume of Postal and } \\
\text { Telecommunication Services } \\
\text { (100 million Yuan) }\end{array}$ & $\mathrm{X}_{10}$ \\
\hline & $\begin{array}{l}\text { Number of Subscribers of Internet } \\
(10000 \text { subscribers })\end{array}$ & $\mathrm{X}_{11}$ \\
\hline \multirow{3}{*}{$\begin{array}{c}\text { Social } \\
\text { development }\end{array}$} & $\begin{array}{l}\text { Number of Hospital Beds per } 10000 \\
\text { Persons (bed) }\end{array}$ & $\mathrm{X}_{12}$ \\
\hline & \begin{tabular}{|l} 
Number of $\quad$ Medical Technical \\
Personnel per 10000 Persons (person)
\end{tabular} & $\mathrm{X}_{13}$ \\
\hline & Engel coefficient & $\mathrm{X}_{14}$ \\
\hline \multirow{3}{*}{$\begin{array}{l}\text { International } \\
\text { development } \\
\text { level }\end{array}$} & Foreign Direct Investment & $\mathrm{X}_{15}$ \\
\hline & $\begin{array}{l}\text { Domestic Tourist Income } \\
(100 \text { million yuan })\end{array}$ & $\mathrm{X}_{16}$ \\
\hline & $\begin{array}{l}\text { Total Value of Imports and Exports (USD } \\
100 \text { million) }\end{array}$ & $\mathrm{X}_{17}$ \\
\hline
\end{tabular}

\section{BREAKING POINT THEORY}

City hinterland refers to the area of aggregation and distribution of passengers and goods. The size of city hinterland is affected by the city nature, natural resources, social and economic factors. The city has the interdependent and interactive relations with the city hinterland. The breaking point theory is widely used in delimiting city abstracted regions and dividing up urban economic regions. Because the theory just gives only one breaking point between two cities, many methods for partitioning space are used. For instance, it can make vertical line through the breaking point on the linked line between the near two cities and linking the near breaking points with smooth lines [12].

The equations are as follow:

$$
D_{A}=\frac{D_{A B}}{1+\sqrt{P_{B} / P_{A}}}
$$

Where,

$D_{A}$ is the distance between breaking point to city A;

$D_{A B}$ is the distance between city A to city B;

$P_{A}$ is the comprehensive strength of city A;

$P_{B}$ is the comprehensive strength of city B;

In traditional way, city population or economic indicators is often used to express comprehensive strength of city. City logistics depends on many aspects, evaluation index system of comprehensive strength of city logistics is used.

\section{EMPIRICAL STUDY OF CITY LOGISTICS}

\subsection{City choosing}

Considering the traffic location, the city economic development, the logistics development of 14 cities in Guangxi is compared in table 2.

Table 2. Development condition of 14 cities in Guangxi

\begin{tabular}{|c|c|c|c|c|c|c|}
\hline City & $\begin{array}{c}\text { Per Capita Gross } \\
\text { Domestic Product } \\
\text { (Yuan) }\end{array}$ & $\begin{array}{l}\text { Total Investment } \\
\text { in Fixed Assets } \\
(100 \text { million } \\
\text { Yuan })\end{array}$ & $\begin{array}{c}\text { Per Capita Annual } \\
\text { Disposable Income of } \\
\text { Urban Households } \\
\text { (Yuan) }\end{array}$ & $\begin{array}{l}\text { Business Volume of } \\
\text { Postal and } \\
\text { Telecommunication } \\
\text { Services } \\
\text { (100 million Yuan) }\end{array}$ & $\begin{array}{c}\text { Total Retail Sales } \\
\text { of Consumer } \\
\text { Goods (100 } \\
\text { million Yuan) }\end{array}$ & $\begin{array}{l}\text { Total Value of } \\
\text { Imports and } \\
\text { Exports (USD } \\
100 \text { million) }\end{array}$ \\
\hline Nanning & 37016 & 2517.61 & 22561 & 4.79 & 1255.59 & 414678 \\
\hline Liuzhou & 47795 & 1615.22 & 22181 & 1.74 & 661.84 & 311593 \\
\hline Guilin & 30849 & 1336.18 & 22300 & 2.17 & 536.3 & 97487 \\
\hline Wuzhou & 28523 & 797.07 & 20563 & 1.26 & 257.20 & 121038 \\
\hline Beihai & 40372 & 707.80 & 21202 & 0.70 & 146.51 & 207761 \\
\hline $\begin{array}{l}\text { Fangcheng- } \\
\text { gang }\end{array}$ & 50302 & 517.83 & 22203 & 0.47 & 71.30 & 489826 \\
\hline Qinzhou & 22147 & 561.68 & 21600 & 1.22 & 237.56 & 376656 \\
\hline Guigang & 16281 & 495.21 & 19314 & 1.79 & 284.05 & 23144 \\
\hline Yulin & 19822 & 969.42 & 22171 & 2.15 & 422.83 & 58807 \\
\hline Baise & 21539 & 916.88 & 19561 & 1.2 & 156.67 & 50866 \\
\hline Hezhou & 19922 & 542.37 & 19855 & 0.63 & 106.39 & 15589 \\
\hline Hechi & 14472 & 221.82 & 17964 & 1.33 & 176.98 & 52444 \\
\hline Laibin & 24183 & 480.11 & 21499 & 0.68 & 109.53 & 14454 \\
\hline Chongzuo & 26288 & 479.99 & 19370 & 0.95 & 84.37 & 13433 \\
\hline
\end{tabular}


Guangxi Beibu Gulf Economic Zone Development Plan was approved by the central government on 16th January 2008, which has brought the development and opening-up of the Economic Zone into the national development strategy. Located in the juncture of South China Economic Rim, Southwest China Economic Rim and ASEAN Economic Rim, and close to the Sea, border and rivers, Guangxi Beibu Gulf Economic Zone serves as the most convenient freight transportation for Southwest China to the sea, a forefront and an important gateway for ChinaASEAN cooperation. As an important city, Fangcheng-gang will be chosen to analyze.

\subsection{Principal component analysis}

Principal component analysis is a mathematical procedure that uses an orthogonal transformation to convert a set of observations of possibly correlated variables into a set of values of linearly uncorrelated variables called principal components. It is used to table 3 . reduce the number of variables comprising a dataset while retaining the variability in the data; identify hidden patterns in the data, and classifying them [1316].

According to the characteristics of traffic location of Fangcheng-gang, other cities in Guangxi region and the peripheral port cities such as Guangzhou, Shenzhen, Wuhan, Changsha, Kunming and Guiyang are selected. Concern about data reliability is a crucial factor that may have a strong effect on evaluation. All the data of seventeen evaluation indexes of 20 cities came from 2013 Guangxi Statistical Yearbook, China Statistical Yearbook 2013 and statistics information network. However, due to limited space, much of the important methodological data is omitted [17].

In order to eliminate the systematic error, the raw and normalized data were analyzed using SPSS software. Then calculate covariance matrix, eigenvalues and eigenvectors of covariance matrix. Eigenvalues and the proportion of variation explained by the principal components are shown in

Table 3 Eigenvalues and the proportion of variation explained by the principal components.

\begin{tabular}{|c|c|c|c|c|c|c|}
\hline \multirow{2}{*}{ Component } & \multicolumn{3}{|c|}{ Initial Eigenvalues } & \multicolumn{3}{|c|}{ Extraction Sums of Squared Loadings } \\
\hline & Total & $\%$ of Variance & Cumulative $\%$ & Total & $\%$ of Variance & Cumulative $\%$ \\
\hline 1 & 7.990 & 61.460 & 61.460 & 7.990 & 61.460 & 61.460 \\
\hline 2 & 1.363 & 10.482 & 71.942 & 1.363 & 10.482 & 71.942 \\
\hline 3 & 1.164 & 8.956 & 80.897 & 1.164 & 8.956 & 80.897 \\
\hline 4 & 0.994 & 7.649 & 88.547 & & & \\
\hline 5 & 0.651 & 5.007 & 93.554 & & & \\
\hline 6 & 0.295 & 2.266 & 95.820 & & & \\
\hline 7 & 0.235 & 1.804 & 97.624 & & & \\
\hline 8 & 0.164 & 1.265 & 98.889 & & & \\
\hline 9 & 0.088 & 0.680 & 99.569 & & & \\
\hline 10 & 0.041 & 0.318 & 99.887 & & & \\
\hline 11 & 0.010 & 0.076 & 99.962 & & & \\
\hline 12 & 0.007 & 0.030 & 99.992 & & & \\
\hline 13 & 0.006 & 0.020 & 100.000 & & & \\
\hline 14 & 0.004 & 0.018 & 100.000 & & & \\
\hline 15 & 0.003 & 0.008 & 100.000 & & & \\
\hline 16 & 0.002 & 0.005 & 100.000 & & & \\
\hline 17 & 0.001 & 0.002 & 100.000 & & & \\
\hline
\end{tabular}

Three principal components were extracted with eigenvalues of 7.990 for the first principal component (F1), 1.363 for the second principal component $(\mathrm{F} 2)$ and 1.164 for the third principal component (F3). The three principal components accounted for $80.897 \%$ of the total variance present in the 17 original variables. This is an acceptably large percentage.

Initial factor loading matrix is shown in table 4.

Principal component scores on the comprehensive and ranking of 20 cities are shown in table 5. 
Table 4 Initial factor loading matrixes

\begin{tabular}{|c|c|c|c|}
\hline & $\mathrm{F} 1$ & $\mathrm{~F} 2$ & $\mathrm{~F} 3$ \\
\hline $\mathrm{X}_{1}$ & 0.104 & 0.047 & -0.002 \\
\hline $\mathrm{X}_{2}$ & 0.021 & 0.107 & 0.028 \\
\hline $\mathrm{X}_{3}$ & 0.115 & -0.022 & -0.018 \\
\hline $\mathrm{X}_{4}$ & 0.041 & -0.019 & -0.001 \\
\hline $\mathrm{X}_{5}$ & 0.081 & 0.048 & -0.026 \\
\hline $\mathrm{X}_{6}$ & 0.103 & -0.025 & 0.049 \\
\hline $\mathrm{X}_{7}$ & 0.107 & 0.008 & 0.039 \\
\hline $\mathrm{X}_{8}$ & 0.080 & -0.047 & -0.057 \\
\hline $\mathrm{X}_{9}$ & 0.093 & -0.047 & -0.032 \\
\hline $\mathrm{X}_{10}$ & 0.105 & -0.034 & -0.031 \\
\hline $\mathrm{X}_{11}$ & 0.102 & -0.014 & 0.042 \\
\hline $\mathrm{X}_{12}$ & 0.111 & 0.013 & 0.016 \\
\hline $\mathrm{X}_{13}$ & 0.082 & 0.035 & -0.014 \\
\hline $\mathrm{X}_{14}$ & 0.122 & 0.003 & -0.004 \\
\hline $\mathrm{X}_{15}$ & 0.102 & -0.044 & -0.015 \\
\hline $\mathrm{X}_{16}$ & 0.111 & 0.003 & -0.033 \\
\hline $\mathrm{X}_{17}$ & -0.028 & -0.026 & 0.091 \\
\hline
\end{tabular}

Table 5 Principal component scores on the comprehensive

\begin{tabular}{|l|c|c|c|c|c|}
\hline City & F1 & F2 & F3 & F & $\begin{array}{c}\text { Rankin } \\
\text { g }\end{array}$ \\
\hline Guangzhou & 2.816 & 0.382 & 0.080 & 3.278 & 1 \\
\hline Shenzhen & 2.067 & 0.281 & -0.090 & 2.258 & 2 \\
\hline Wuhan & 1.803 & 0.381 & 0.038 & 2.222 & 3 \\
\hline Changsha & 1.887 & 0.207 & 0.038 & 2.132 & 4 \\
\hline Nanning & 1.913 & 0.180 & -0.013 & 2.080 & 5 \\
\hline Liuzhou & 1.023 & 0.098 & -0.151 & 0.970 & 6 \\
\hline Fangcheng-gang & 0.089 & 0.901 & -0.021 & 0.969 & 7 \\
\hline Kunming & 1.018 & 0.024 & -0.116 & 0.926 & 8 \\
\hline Guilin & 0.078 & 0.182 & 0.110 & 0.370 & 9 \\
\hline Guiyang & -0.283 & 0.163 & 0.016 & -0.104 & 10 \\
\hline Beihai & -0.461 & 0.079 & 0.230 & -0.152 & 11 \\
\hline Qinzhou & -0.478 & 0.079 & 0.228 & -0.171 & 12 \\
\hline Guigang & -0.488 & 0.051 & 0.248 & -0.189 & 13 \\
\hline Wuzhou & 0.005 & -0.080 & -0.119 & -0.194 & 14 \\
\hline Yulin & 0.012 & -0.041 & -0.173 & -0.202 & 15 \\
\hline Baise & -0.463 & -0.053 & 0.295 & -0.221 & 16 \\
\hline Hezhou & -0.460 & -0.077 & 0.305 & -0.232 & 17 \\
\hline Hechi & -0.420 & 0.035 & 0.147 & -0.238 & 18 \\
\hline Laibin & -0.495 & -0.112 & 0.27 & -0.267 & 19 \\
\hline Chongzuo & -0.516 & -0.133 & 0.249 & -0.288 & 20 \\
\hline
\end{tabular}

As can be seen from the table 5, Guangzhou is the most competitive city, followed by Shenzhen, Wuhan, Changsha, Nanning and Liuzhou. The last one is Chongzuo. The results show that city logistics and city economy are positively correlated.

\subsection{City hinterland}

The comprehensive score of the city is the relative value, so some of which are positive and some of which are negative. Therefore, it is needed to carry on the data conversion to positive for the center intensity value. Then use the breaking point formula to calculate the breaking point for the group of cities. The center intensity value of Fangcheng-gang is 1.979. The other value of competitive cities are shown in table 6 .

Table 6 The breaking point of City

\begin{tabular}{|l|c|c|c|c|}
\hline \multicolumn{1}{|c|}{ City } & $\begin{array}{c}\text { Comprehensiv } \\
\text { e strength }\end{array}$ & $\begin{array}{c}\text { Center } \\
\text { intensit } \\
\mathrm{y}\end{array}$ & $\begin{array}{c}\text { straig } \\
\text { ht } \\
\text { stretc } \\
\mathrm{h} \\
(\mathrm{km})\end{array}$ & $\begin{array}{c}\text { The } \\
\text { distance of } \\
\text { breaking } \\
\text { point }(\mathrm{km})\end{array}$ \\
\hline Guangzhou & 3.278 & 4.288 & 530 & 214 \\
\hline Shenzhen & 2.258 & 3.268 & 596 & 261 \\
\hline Wuhan & 2.222 & 3.232 & 1185 & 520 \\
\hline Changsha & 2.132 & 3.142 & 900 & 398 \\
\hline Nanning & 2.080 & 3.090 & 127 & 56 \\
\hline Liuzhou & 0.970 & 1.980 & 313 & 156 \\
\hline Kunming & 0.926 & 1.936 & 740 & 372 \\
\hline Guilin & 0.370 & 1.380 & 445 & 242 \\
\hline Guiyang & -0.104 & 0.906 & 640 & 382 \\
\hline Beihai & -0.152 & 0.858 & 83 & 50 \\
\hline Qinzhou & -0.171 & 0.839 & 45 & 27 \\
\hline Guigang & -0.189 & 0.821 & 207 & 126 \\
\hline Wuzhou & -0.194 & 0.816 & 360 & 219 \\
\hline Yulin & -0.202 & 0.808 & 213 & 130 \\
\hline Baise & -0.221 & 0.789 & 312 & 191 \\
\hline Hezhou & -0.232 & 0.778 & 445 & 274 \\
\hline Hechi & -0.238 & 0.772 & 342 & 211 \\
\hline Laibin & -0.267 & 0.743 & 250 & 155 \\
\hline Chongzuo & -0.288 & 0.722 & 133 & 83 \\
\hline
\end{tabular}

Because the comprehensive strength of Guangzhou, Shenzhen, Wuhan, Changsha is more strong, hinterland of Fangcheng-gang respectively extruded eastward direction and northeast direction. In the Kunming direction, the hinterland covers Funing County in Yunnan. In the Guiyang direction, the hinterland arrives in Donglan County of Guangxi. In the Guangxi region, the hinterland area covers almost the midpoint of each city.

The hinterland of Fangcheng-gang has the following characteristics. Firstly, as the largest port city of Guangxi, the direct economic hinterlands are Qinzhou, the southwest part of Baise and Nanning. Indirect economic hinterland is other areas of Guangxi region, the southwest of Yunnan and Guizhou, the western of Hunan and Hubei. Secondly, as the core city, the northeast and northwest of Fangcheng-gang is wide distribution. It basically follows the rules of distance decay. The closer between two cities, the more linked. In the southeast, the competition with Zhanjiang, Shenzhen and Guangzhou is especially fierce.

\section{CONCLUSIONS}

Covering Qinzhou, coastal industrial zone and related coastal area, Fangcheng-gang will build bonded port area, develop coastal heavy chemical industry and port logistics. A processing and manufacturing base and logistics base will be made to use both domestic and international markets and 
resources. It need to identify port functions to promote comprehensive development of port and build Guangxi coastal port cluster, strengthen the transportation system of energy, iron ore and containers and the collecting, distributing and dredging system that links hinterland and improve handling capacity of coastal ports. It is useful to establish complete high grade highway and railway network to connect Southwest, Central and South of China.

\section{ACKNOWLEDGMENT}

This research is supported by "the Fundamental Research Funds for the Central Universities" (2014JBM061)

\section{REFERENCES}

[1] Frederic M. Scherer and David Ross. 1990. Industrial Market Structure and Economic Performance, 3rd ed. NewYork: Houghton Mifflin Company.

[2] D. J. Patton. 1958. General cargo hinterland of New York, Philadelphis, Baltimore and New Orleans. Annals of the Association of American Geographers, 48(4):436-455.

[3] FYV Morgan. 1958. Ports and harbors. London: Hutchison Press.

[4] H. M. Mayer. 1957. The port of Chicago and the St. Lawrence Seaway. Development of Geography Research Papers, 49(1): 30-34.

[5] Jay.W.Forrester. 1968. Principles of System. Cambridge: Wright-Allen press, Inc.
[6] Wang Jie, Yang Zan, Lu Chun-feng. 2005. Two New Methods for Partitioning Port Hinterland. Navigation of China. 64(3): 57-61

[7] Xie Tongwei, Bin Changchu. 2007. Disscusions about the Economic Hinterland of the Port in Guangxi Beibu Bay. Around Southeast Asia. (12):60-62

[8] Yan Weiyang, Qin Yaochen, Guo Qingsheng. 2004. Expanding, Validation and Application of Urban Breaking Point Theory. Human Geography. 19(2): 12-16

[9] Zhang Pingping. 2012. The Study on the Evaluation of Logistics Industry Competitiveness of Shanxi Province. Master's degree thesis. North University of China.

[10]Zhao Liqin, Guo Yuexian. 2011. Research on City Logistics Competitiveness Evaluation Method. Areal Research and Development. 30(2): 78-81.

[11]Gao Junlin. 2011. A Comparative Study on the Logistic Competition of Central Cities in Central China. Master's degree thesis. Guangzhou University.

[12]Lu Zhelu, Chen Chuan, Li Fazhi. 2013. The logistics development Countermeasures in a mediun-sized city based on its traffic location - take Luzhou as an example. Logistics Sci-Tech. 2013(7): 76-80.

[13]Jolliffe, I. T. 2002. Principal Component Analysis. 2nd ed. New York: Springer.

[14]Toshinori Nemoto, Johan Visser, Ryuichi Yoshimot. 2008. Impacts of Information and Communication Technology on Urban Logistics System. Transportation Research Part. (32):45-47.

[15]Crainic Teodor Gabriel, Ricciardi Nicoletta, Storchi, Giovanni. 2009. Models for Evaluating and Planning City Logistics Systems. Transportation Science. (43):432-454.

[16]Huang Chuankun, Wang Yuanqing. 2011. The application of principal component analysis method. Modern Business Trade Industry. (23):26-28.

[17]Compiled by Guangxi Statistics Bureau. 2013. 2013 Guangxi Statistical Yearbook. China Statistics Press. Beijing. 